\title{
Seasonal Changes in Carbon Content, and Dehydrogenase, Phosphatase, and Urease Activities in Mixed Prairie and Fescue Grass- land Ah Horizons
}

\author{
J.F. DORMAAR, A. JOHNSTON, AND S. SMOLIAK
}

\begin{abstract}
Total C, water-soluble $C$, and 3 soil enzymes associated with $\mathbf{A h}$ horizons under ungrazed mixed prairie and fescue grassland ranges were assessed over a 23 -month period. Generally, total C was higher in samples from heavily grazed sites than in those from ungrazed sites and was higher over the winter months than during the summer. Water-soluble $\mathbf{C}$ was generally higher in soil from mixed prairie than in soil from fescue grassland except for short periods during the winter. Enzymatic activities are highest in samples from the fescue grassland site regardless of grazing intensity. Enzymatic activities of both sites increased during the winter months. Grazing intensity affected enzymatic activities differently at the $\mathbf{2}$ sites. A working hypothesis is proposed to account for organic matter breakdown during the winter and spring months.
\end{abstract}

Many soil biological processes are related to the decomposition of organic residues which in prairie soils come predominantly from plant roots. This decomposition varies with seasons. In a 3-year study of blue grama (Bouteloua gracilis), over $50 \%$ of the root mass disappeared between October and May each year (Dormaar et al. 1981). Although only fragmentary information is available on year-round enzymatic soil activities, Khaziyev (1977) has shown that the annual pattern for $\mathrm{CO}_{2}$ liberation reached a maximum when the soil was frozen and that the potential for enzymatic activity increased in winter and early spring but decreased in the summer. Since water-soluble $C$ is a measure of soluble, low molecular weight organic compounds, they can act as substrates for biological processes (Ivarson and Sowden 1970). Seasonal changes in soil enzymatic activity (Kiss et al. 1975, Khaziyev 1977), and changes in the amount and condition of the substrate upon which they act, may thus be related to any seasonal changes in rates of biological processes in the soil.

Generally enzymes accumulated in soil have biological significance as they participate in the cycling of elements and thus play a very important role in the initial phases of the decomposition of organic residues (Kiss et al. 1975). Specifically, dehydrogenase activity in soils provides correlative information on the biological activity and microbial populations; phosphatase activity is thought to be directly related to the level of organic phosphorus in the soil; urease activity generally correlates with organic matter content due to its existence as a complex with organic constituents (Skujins 1973, 1976).

The purpose of this study was to assess over a 2-year period several characteristics that could be related to soil organic matter breakdown in ungrazed and heavily grazed mixed prair-

\footnotetext{
Authors are soil scientist, retired range ecologist, and range ecologist, respectively, Research Station, Agriculture Canada, Lethbridge, Alberta, T1J 4BI.

The willingness with which the employees of the Water Treatment Plant at Claresholm, Alta., gave access to their metereological data file is greatly appreciated.

Manuscript received February 1, 1981
}

ie and fescue grassland range.

\section{Materials and Methods}

The study was conducted at the Agriculture Canada Research Substations near Manyberries and Stavely, Alberta. In 1978, 2 fields were selected at each Substation and 3 plots were delineated in each field.

The vegetation of the Manyberries study site is typical of the Stipa-Bouteloua faciation of the mixed prairie association (Coupland 1961). The soil is a member of the brown solod subgroup of the solonetzic order. Climate is semiarid and annual precipitation averages about $310 \mathrm{~mm}$. Fields were an ungrazed enclosúre protected since 1928 (Smoliak 1974) and an adjacent field heavily grazed ( 1.7 ha/ AUM) for 19 years by ewes with lambs during the period May 1 to November 1 .

The vegetation of the Stavely study site is typical of the fescue grassland association (Coupland and Brayshaw 1953). The soil is a member of the orthic black subgroup of the chernozemic order. Climate is dry subhumid and annual precipitation averages about $500 \mathrm{~mm}$. Fields studied were an ungrazed enclosure, protected since 1949 , and an adjacent field, heavily grazed ( 0.2 ha/AUM) by cows with calves since 1951 . The field was grazed from May 15 to November 15 until about 1962 when because of deterioration of cover, the grazing season was reduced to 2.5 to 5 months.

The surface of the $\mathrm{Ah}(=\mathrm{A} 1)$ horizon may be defined as a mineral horizon in which accummulated organic matter is intimately associated with the mineral fraction. This horizon further contains between 70 and $90 \%$ of the native range root mass. Most of the biological processes that occur in the soil will thus occur in this zone. The Ah horizon was therefore sampled on 3 subplots in each of the 3 plots within each study site at monthly intervals from July 1978 to June 1980 . Immediately after sampling and when appropriate after thawing out, the subplot samples were combined, mixed, hand-sieved through a $2-\mathrm{mm}$ screen, and stored in sealed, double polyethylene bags at $4^{\circ} \mathrm{C}$. At the time of sieving, roots and other debris were removed from the soil and discarded. Moisture content of the soil was determined by drying overnight at $105^{\circ} \mathrm{C}$.

Total C was determined by dry combustion. Water-soluble C was determined by adding sufficient distilled water to moist soil ( 25 g oven-dry) to produce a combined water volume (soil moisture + added water) of $100 \mathrm{ml}$. The soil-water mixtures were shaken for 1 $h$ and centrifuged at $37,000 \mathrm{~g}$ at $R_{\max }$ for $30 \mathrm{~min}$. The supernatant was filtered through a $0.22-\mu \mathrm{m}$ Millipore filter and the $\mathrm{C}$ content determined by the Walkley-Black method (Black 1965). Root debris remaining in the soil samples after sieving was obtained by a flotation process (Thompson 1965).

Dehydrogenase and phosphatase activities were determined on 


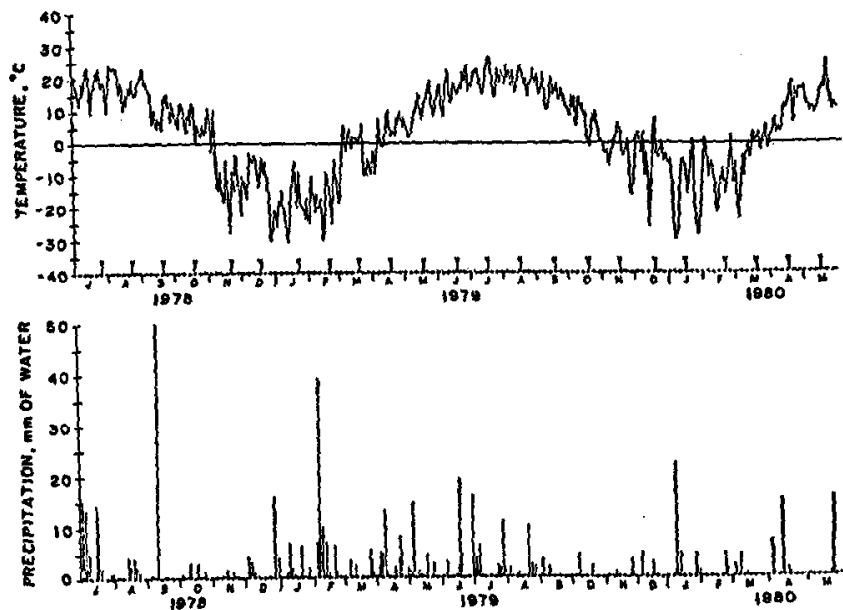

Fig. 1. Daily mean temperature and precipitation for rain and snow for the Manyberries Substation from July 1, 1978, to May 31, 1980. (Sampling dates are marked above the $X$-axis of the temperature graph.)

the fresh, moist soil within 24 and $48 \mathrm{~h}$, respectively, after its collection from the field to avoid changes in the activities. Dehydrogenase activity was determined at $\mathrm{pH} 7.6$ by measuring the triphenylformazan (formazan) produced by reduction of $2,3,5-$ triphenyltetrazolium chloride when soil was incubated with 2amino-2-(hydroxymethyl)propane-1:3-diol buffer $(0.5 \mathrm{M})$ at $30^{\circ} \mathrm{C}$ for 5 hours (Ross 1971). Phosphatase activity was determined at pH 6.5 by measuring the $p$-nitrophenol produced when soil was incubated with buffered sodium $p$-nitrophenyl phosphate solution $\left(0.115 \mathrm{M}\right.$ ) and toluene at $37^{\circ} \mathrm{C}$ for 1 hour (Tabatabai and Bremner
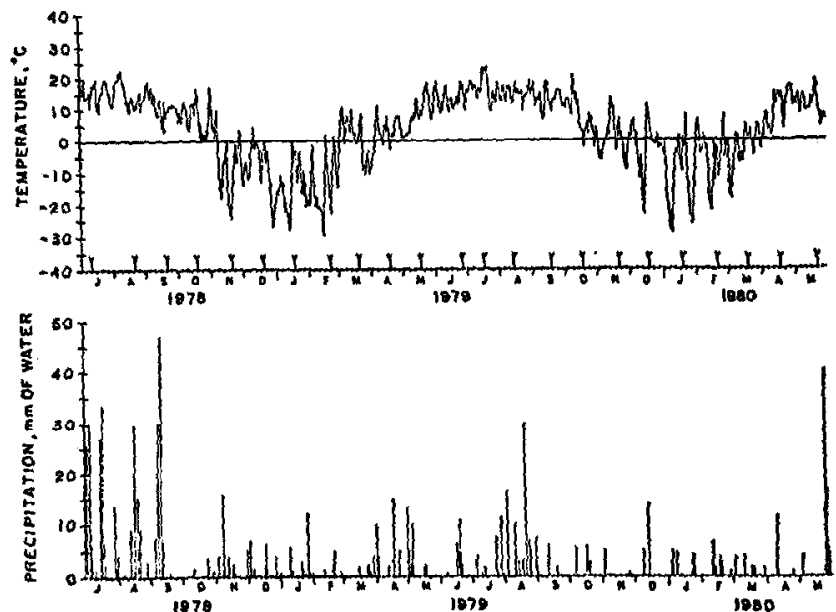

Fis. 2. Daily mean temperature and precipitation for rain and snow for the Stavely Substation-Claresholm area from July 1, 1978, to May 31, 1980. (Sampling dates are marked above the $X$-axis of the temperature graph.)

1969). Urease activity was determined on air-dry soils at $\mathrm{pH} 9.0$ by incubating with tris (hydroxymethyl)aminomethane buffer $(0.05$ M), urea solution, and toluene at $37^{\circ} \mathrm{C}$ for 2 hours, and measuring the ammonium released after steam distillation (Tabatabai and Bremner 1972). All analytical results are expressed on the basis of oven-dry weight of soil. Standard errors were calculated for each field for each sampling date. To enhance the readability of the various figures, the largest standard error has been presented at the end of each graph.

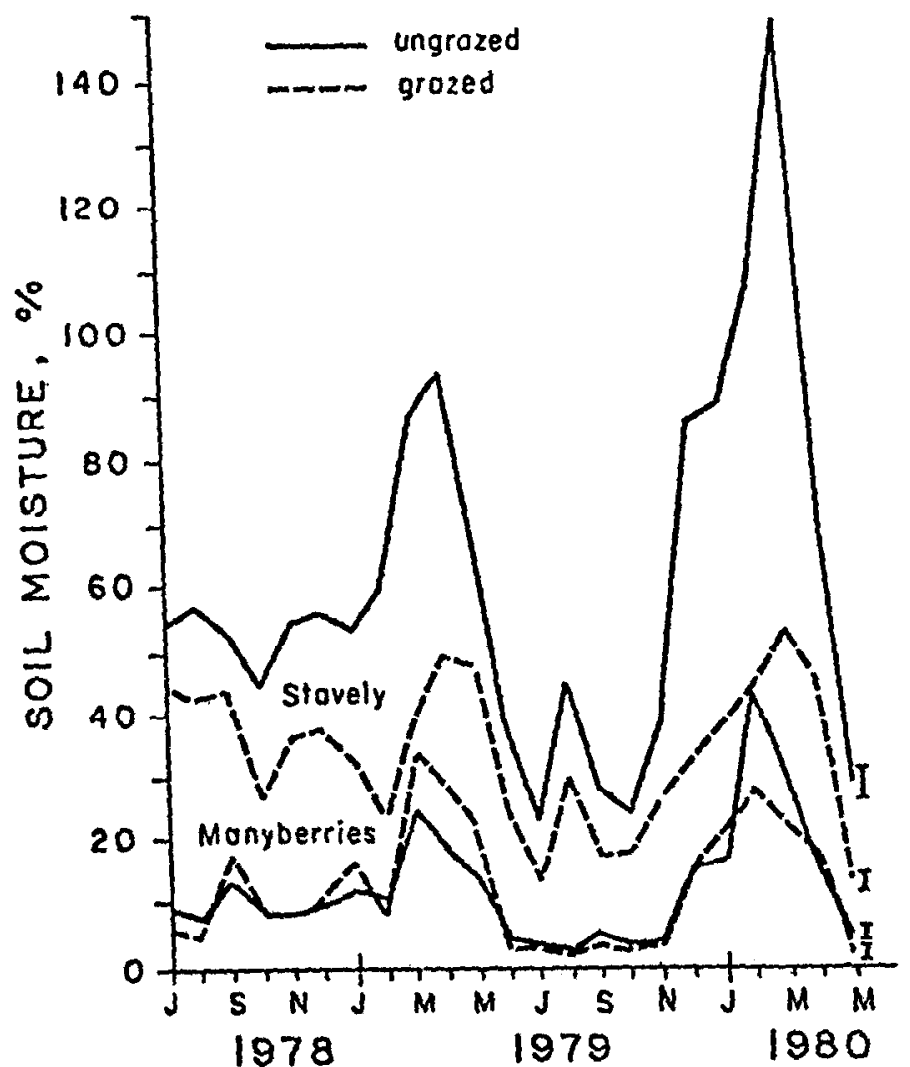

Fig. 3. Seasonal fluctuations of soil moisture in Ah horizons of heavily grazed and ungrazed grasslands at the Manyberries and Siavely Substations, Alberta, from July 1978 through May 1980.

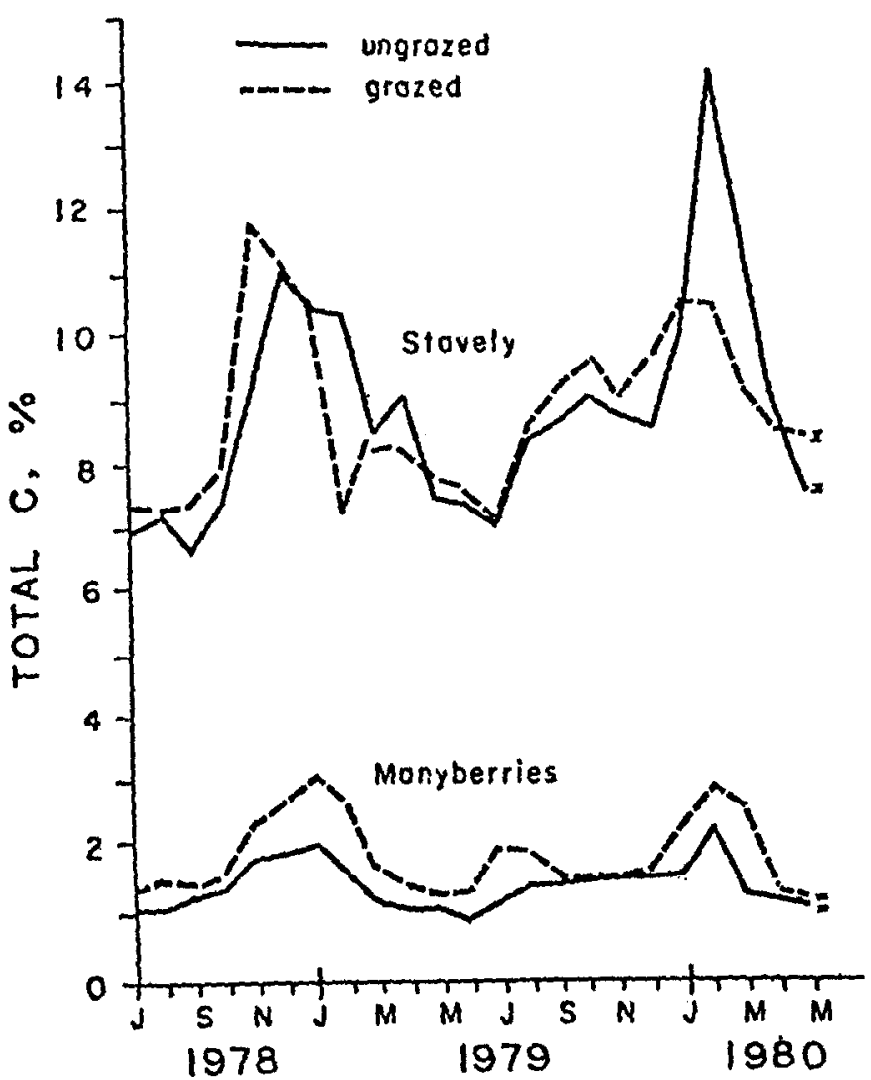

Fig. 4. Seasonal fuctuations of total soil $C$ in Ah horizons of heavily grazed and ungrazed grassiands at the Manyberries and Stavely Substations, Alberta, from July 1978 through May 1980. 
The temperature and precipitation data (Fig. 1) for the Manyberries area were collected at the Substation Headquarters. The data for the Stavely area (Fig. 2) were collected at the Substation Headquarters from July 1 to October 31, 1978, from April 23 to November 7, 1979, and from April 21 to May 31, 1980, and at the Water Treatment Plant of the Town of Claresholm, about $50 \mathrm{~km}$ SE of the Stavely Substation, for the remaining dates. The mean daily air temperatures were calculated and snow was expressed as millimeters of water equivalent.

\section{Results}

\section{Soil Moisture}

Soil moisture levels (Fig. 3) generally followed the precipitation pattern during the months that the ground was not frozen (Figs. 1 \& 2 vs Fig. 3). However, in late winter and early spring, soil moisture increased substantially probably due to the absorption of snowmelt into the Ah horizon while the B horizon was still frozen during periods of above $0^{\circ} \mathrm{C}$ mean air temperatures (Fig. $1 \& 2$ ). However, considerable upward movement of moisture may be thermally induced during the winter months as well (Ferguson et al. 1964).

\section{Total and Water-soluble $C$}

At both locations, total $\mathrm{C}$ was generally higher in soil of the heavily grazed than the ungrazed fields (Fig. 4). The exception was during late winter/early spring at the Stavely site. At both locations, total $C$ was higher over the winter months as compared to the summer months. Even though the freezing and thawing of the Ah horizon over the winter months could have mechanically reduced the size of the roots to less than $2 \mathrm{~mm}$, floatable organic matter (2-mm size) was no greater in the winter samples. It may be postulated that, from fall to spring, moderate humification, prior to mineralization as the soil warms up, of the root debris prevented it from being floatable organic matter. Duchaufour (1973) suggested that one of the origins of the properties of humin was by inheritance through moderate transformation of original organic matter.

Water-soluble $\mathrm{C}$ was generally higher in soils from the Manyberries site than from the Stavely site except around November/December 1978 and February/March 1980 (Fig. 5). Water-soluble C was generally higher in soil of the ungrazed field than in soil of the heavily grazed field at the Manyberries site while the reverse was generally true for the Stavely soils.

\section{Dehydrogenase Activity}

In spite of the difference in dehydrogenase activity between the 2 locations (Fig. 6), the seasonal trends were identical with high potential activities during the winter months and low activities during the summer months. There were only small differences between the 2 grazing regimes at the Manyberries site, while the dehydrogenase activity was generally greater in soil of the ungrazed field than in soil of the heavily grazed field at the Stavely site.

\section{Phosphatase Activity}

The phosphatase activities differed between the 2 locations but the seasonal trends were similar with higher potential activities during the winter months than during the summer months (Fig. 7). At Manyberries, the phosphatase activity in soil of the heavily grazed field was decidedly greater than in soil of the ungrazed field, while the reverse was generally true for the Stavely soils.

\section{Urease Activity}

The seasonal patterns for urease activities for the 4 fields were generally the same (Fig. 8). At Manyberries, urease activity in soil of the ungrazed field was greater than in soil of the heavily grazed field, while the reverse was true for the Stavely soils.

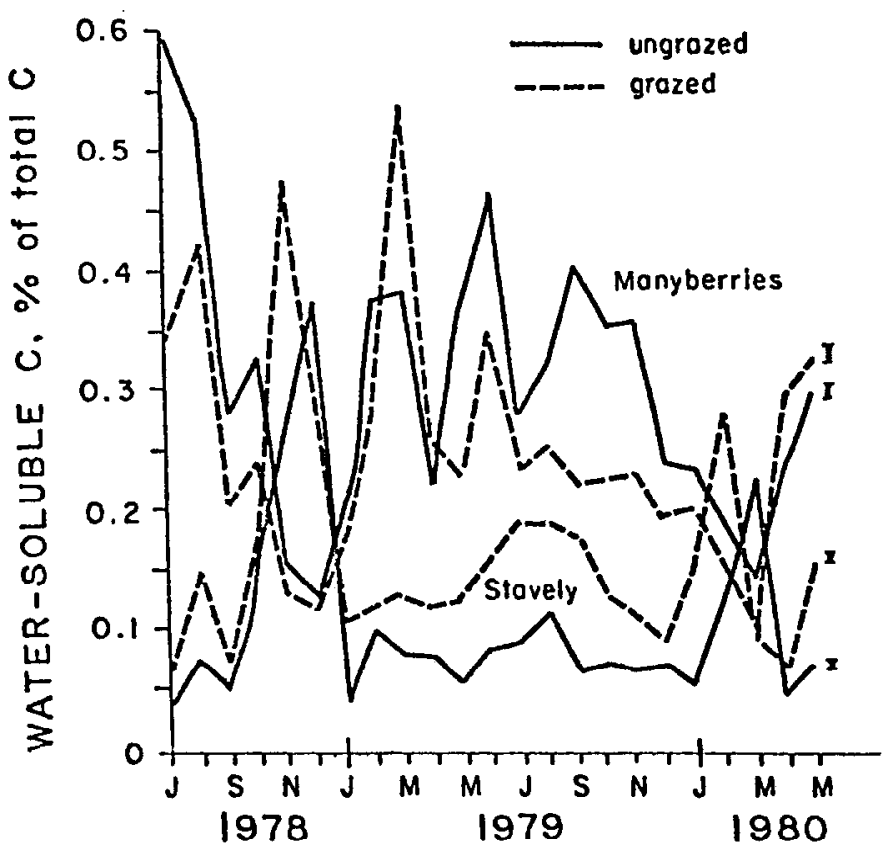

Fig. 5. Seasonal fluctuations of water-soluble $C$ in Ah horizons of heavily grazed and ungrazed grasslands at the Manyberries and Stavely Substations, Alberta, from July 1978 through May 1980.

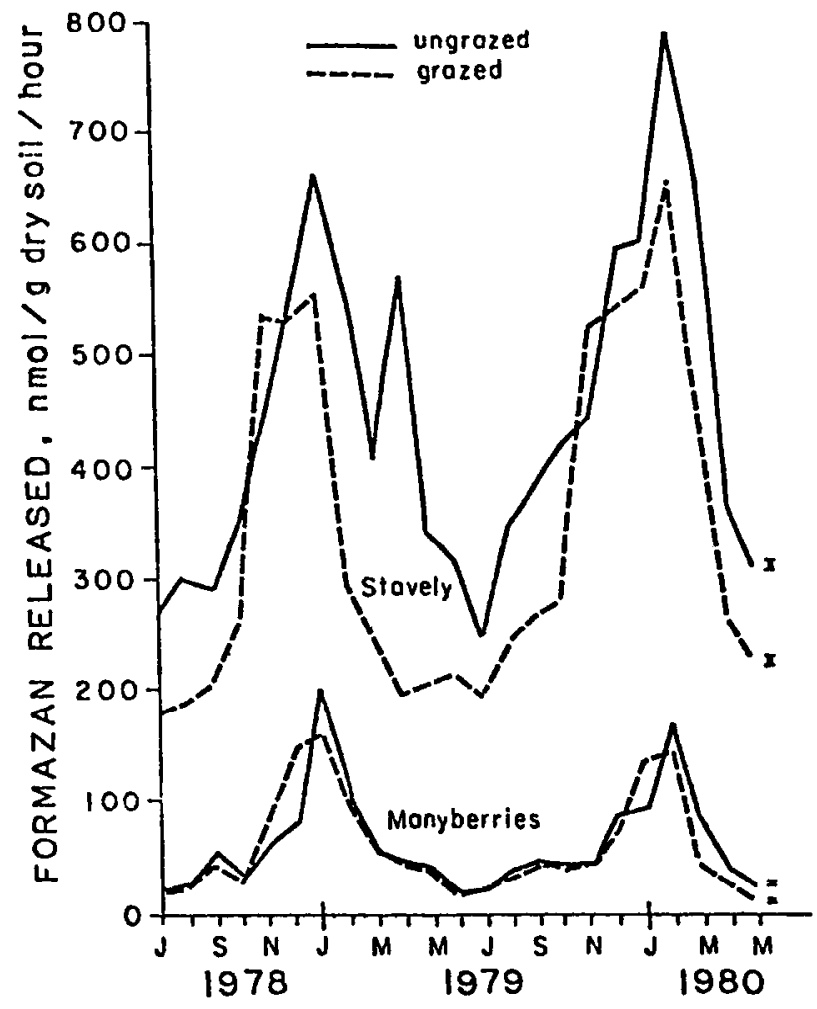

Fig. 6. Seasonal fluctuations of dehydrogenase activity in Ah horizons of heavily grazed and ungrazed grasslands at the Manyberries and Stavely Substations, Alberta, from July 1978 through May 1980. 


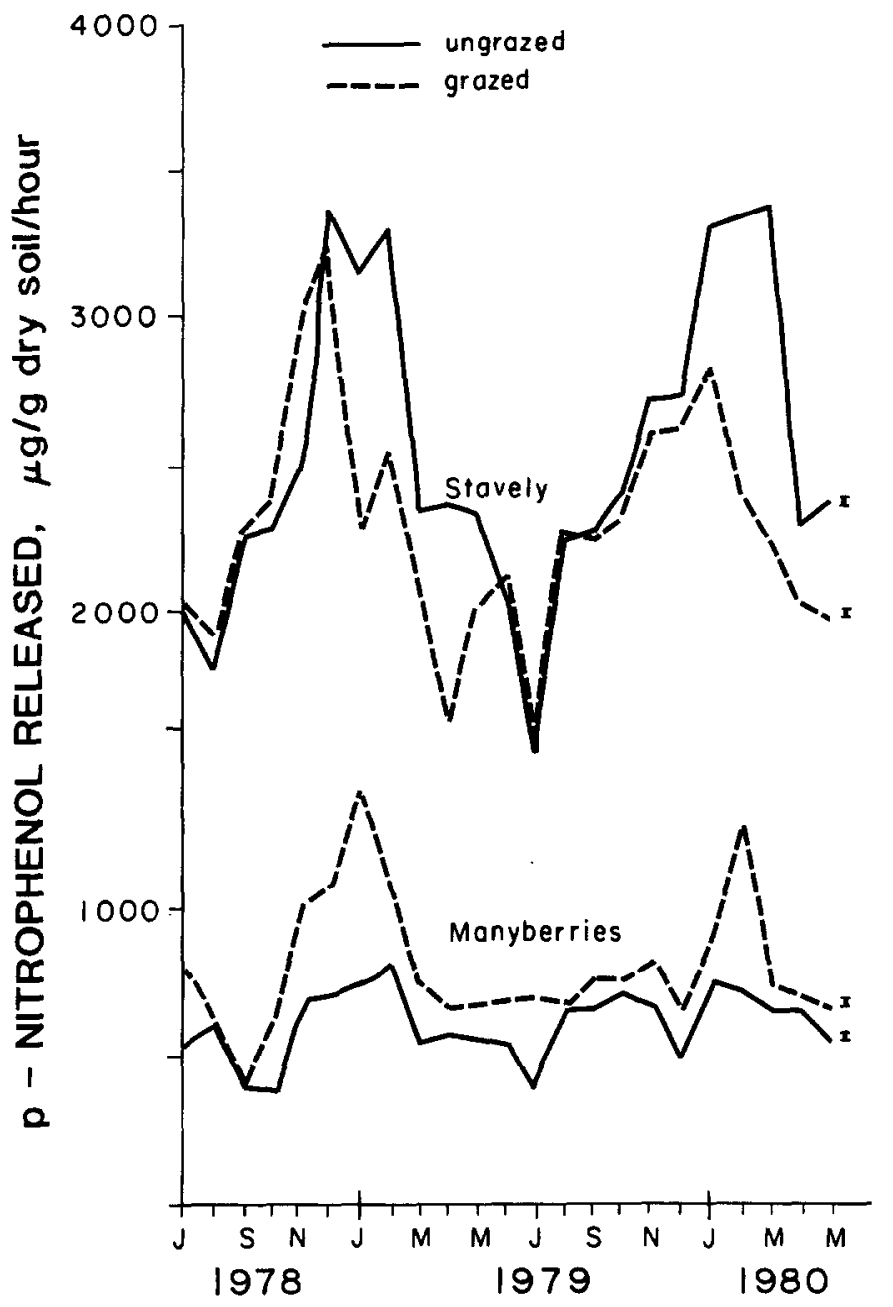

Fig. 7. Seasonal fluctuations of phosphatase activity in Ah horizons of heavily grazed and ungrazed grasslands at the Manyberries and Stavely Substations, Alberta, from July 1978 through May 1980.

\section{Discussion}

\section{Enzymatic Activities}

Skujins (1976) noted that seasonal variations in enzymatic activities were generally small; once the enzymes become stabilized in soil they manifest resistance to humidity, temperature, and to various environmental changes. Conversely, our results were consistent with findings reported by Khaziyev (1977) and Salfeld and Sochtig (1977) and indicated that, under the 2 grazing regimes superimposed onto 2 different vegetation types, there were considerable seasonal fluctuations in total $C$ content and enzymatic activities. In spite of different levels of enzymatic activity among the grazing regimes and locations, the common denominator among all enzymatic activities was the increased potential for activity during the winter months.

Even though 1978 was one of the wettest and 1979 one of the drier years over a 77 -year period, the trends for $C$ content and enzymatic activities were the same over the 23 -month sampling period regardless of location of grazing regime. The increased enzymatic activity over winter is supported by Stott and Hagedorn (1980), who identified a negative correlation between urease and soil temperature for inclusion in a best-fit equation for urease activity.

Although dehydrogenase activity is generally related to soil organic matter content, this was not the case in the present study in either area; however, this relationship did hold between the 2 areas. Since dehydrogenase activity decreases when soils are dried, it may well be that in spite of the grazing regime, the hygrothermal conditions (soil moisture and soil temperature) were the overriding

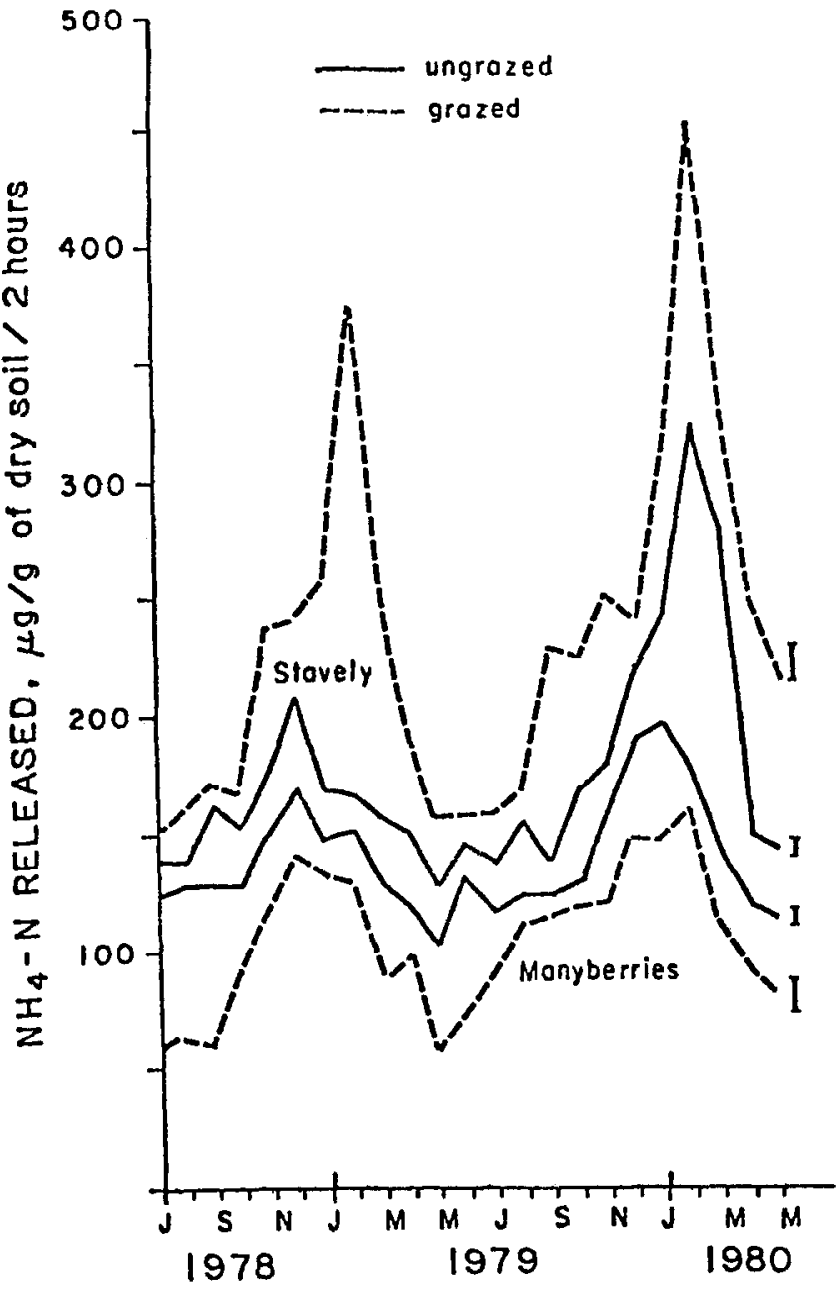

Fig. 8. Seasonal fluctuations of urease activity in Ah horizons of heavily grazed and ungrazed grasslands at the Manyberries and Stavely Substations, Alberta. from July 1978 through May 1980.

factors. Phosphatases are adaptive enzymes and the intensity of the excretion by plant roots and microorganisms is apparently determined by their need for phosphates (Skujins 1976). Thus we may postulate that, with the greater root mass under the heavily grazed and ungrazed conditions in the semiarid and dry sumhumid areas, respectively, phosphatase activity levels will be increased. Urease is primarily produced by microbial and fungal organisms (Skujins 1976). Even though variation in organic matter content accounts for most of the variation in urease activity, factors other than organic matter content must obviously be operating in the 2 areas examined.

It would be more appropriate to consider our enzymatic values to be 'potential' activities because they were all determined at the same temperature in the laboratory $\left(30\right.$ or $\left.37^{\circ} \mathrm{C}\right)$ rather than at the monthly temperatures existing in the field. Still, even though the enzymatic activities of samples obtained during the winter months in this study were thus measured at temperatures higher than in the field, storage at $-20^{\circ} \mathrm{C}$ for 11 weeks and subsequent thawing enhanced dehydrogenase activity in samples of 5 of 8 grassland topsoils (Ross 1970). An increase of dehydrogenase activity, after 3 weeks of storage at $-14^{\circ} \mathrm{C}$, was also shown in 2 of the 3 soils studied by Ivarson and Sowden (1970).

Campbell et al. (1970) and Biederbeck and Campbell (1971) established that diurnally fluctuating temperatures $\left(14\right.$ to $\left.3^{\circ} \mathrm{C}\right)$ in autumn and spring were lethal to the soil microflora. Microorga 
nisms may also be destroyed directly by ice crystals. On the basis of the results reported here, we suggest that, as winter approaches, enzymes, by whatever route, are released into the soil environment. This leads to maximum levels of potential enzymatic activity around February. Some of the enzymes may become ineffective, but others are able to react with the soil organic matter when the soil warms up. Thus, in early spring enzymatic activity levels would be lower, as shown in this study, and root mass reduced, as shown previously (Dormaar et al. 1980).

Although the enzyme-substrate reactions increase in intensity as the soil warms up, there is evidence that some enzymatic activity occurs even below $0^{\circ} \mathrm{C}$. Bremner and Zantua (1975) have shown that significant enzymatic activity occurs in soils at -10 and $-20^{\circ} \mathrm{C}$. This was attributed to enzyme-substrate interaction in unfrozen water at the surfaces of soil particles, because, as soil freezes, an unfrozen film of water is formed between the growing ice lens and the soil particles (Miller et al. 1960). Further autolysis of soil microbial cells killed over winter provides easily accessible sources of energy, such as free amino acids and sugars (Ivarson and Sowden 1970), that set the stage for a natural 'priming effect'.

\section{Root Decomposition}

The chemical composition of the roots in the fall may affect root decomposition over winter as well (Dormaar et al. 1981). The decomposition index ( $\mathrm{C}: \mathrm{N})\left(\%\right.$ lignin) $/\left(\%\right.$ carbohydrate $\left.{ }^{-0.5}\right)$, developed by Herman et al. (1977), helps to predict relative rates of decomposition. A lower index is an indication of potentially lower resistance to breakdown. Dormaar et al. (1981) established values of 65 and 62 for blue grama roots collected at October 10, 1974, and October 1, 1975, respectively. The decomposition index for rough fescue roots collected October 2, 1975, was 134 (J.F. Dormaar, calculated from unpublished data). These values peaked at 106 (May 21, 1975), 104 (May 11, 1976), and 212 (May 9, 1976), respectively, early in the following year. However, there is evidence that a portion of the total $C$ increase found overwinter is of inorganic origin (Dormaar and Sauerbeck 1983).

\section{Working Hypothesis of Overwinter Root Mass Changes}

The mechanism for the different responses to grazing between the 2 locations was examined previously (Johnston et al. 1971; Smoliak et al. 1972). The present data further confirm the effects of grazing on soil organic matter characteristics. However, even though the organic matter of the soil of the Stavely location generally responded to grazing and seasonal pressures independently while these 2 pressures interacted for the soil of the Manyberries location, both sites and both grazing regimes showed similar trends for $\mathrm{C}$ content and enzymatic activites over the season. From this a conceptual model or working hypothesis has been developed to explain the breakdown of root material under semiarid to subhumid conditions during the period from late autumn to early summer. Because of the relationship of the $\mathrm{C}: \mathrm{N}$ ratio and lignin and carbohydrate content of the root mass accumulated by autumn, this root mass goes into the winter with a low resistance to decomposition (Dormaar et al. 1981). A portion of the root mass will be reduced in size by initial freezing and thawing of the soil and probably partly transformed with minimal loss of $\mathrm{CO}_{2}$ during late autumn/early winter. This leads to increased $\mathrm{C}$ content in the soil and increased low molecular weight organic matter in the soil solution.

As winter progresses, microbial death and subsequent lysis releases enzymes into the soil and this increases the potential enzymatic activity of the soil. Death of microorganisms also adds to the low molecular weight organic matter content of the soil solution. As soon as the surface layer of the soil starts to thaw in spring, enzyme-root mass interactions intensify. This reduces enzymatic activity levels and is followed by microorganism-root mass interactions 'primed' by the low molecular weight organic matter in the soil solution. This in turn reduces the root mass and the low-molecular weight organic matter levels in the soil solution.
Application of this hypothesis specifically to the effects of phosphatase activities helps to explain the overwinter buildup of soil organic phosphorus reported earlier (Dormaar 1972) and the rapid decline that follows in spring.

\section{Literature Cited}

Biederbeck, V.O., and C.A. Campbell. 1971. Influence of simulated fall and spring conditions on the soil system. I. Effect on soil microflora. Soil Sci. Soc. Amer. Proc. 35:474-479.

Black, C.A. 1965. Methods of soil analysis. Part 2. Chemical and microbiological properties. Agronomy 9:771-1572.

Bremner, J.M., and M.I. Zantua. 1975. Enzyme activity in soils at subzero temperatures. Soil Biol. Biochem. 7:383-387.

Campbell, C.A., V.O. Biederbeck, and F.G. Warder. 1970. Simulated early spring thaw conditions injurious to soil microflora. Can. J. Soil Sci. 50:257-259.

Coupland, R.T. 1961. A reconsideration of grassland classification in the Northern Great Plains of North America. J. Ecol. 53:475-507.

Coupland, R.T., and F.C. Brayshaw. 1953. The fescue grassland of Saskatchewan. Ecology 34:386-405.

Dormaar, J.F. 1972. Seasonal pattern of soil organic phosphorus. Can. J. Soil Sci. 52:107-112.

Dormaar, J.F., and D.R. Sauerbeck. 1983. Seasonal effects on photoassimilated carbon-14 in the root system of blue grama and associated soil organic matter. Soil Biol. Biochem. 15:475-479.

Dormaar, J.F., S. Smoliak, and A. Johnston. 1981. Seasonal fluctuations of blue grama roots and chemical characteristics. J. Range Manage. 34:62-64.

Duchaufour, Ph. 1973. Action des cations sur les processus d humification. Sci. Sol. 1973 (3):151-161.

Ferguson, H., P.L. Brown, and D.D. Dickey. 1964. Water movement and loss under frozen soil conditions. Soil Sci. Soc. Amer. Proc. 28:700-703.

Herman, W.A., W.B. McGill, and J.F. Dormaar. 1977. Effects of initia] chemical composition on decomposition of roots of three grass species. Can. J. Soil Sci. 57:205-215.

Ivarson, K.L., and F.J. Sowden. 1970. Effect of frost action and storage of soil at freezing temperatures on the free amino acids, free sugars and respiratory activity of soil. Can. J. Soil Sci. 50:191-198.

Johnston, A., J.F. Dormaar, and S. Smoliak. 1971. Long-term effects on fescue grassland soils. J. Range Manage. 24:185-188.

Khaziyev, F. Kh. 1977. Dynamics of the enzymic activity in the Chernozems of the Cis-Ural region. Soviet Soil Sci. 1977:552-563.

Kiss, S., M. Dragan-Bularda, and D. Radulescu. 1975. Biological significance of soil enzymes accumulated in soil. Adv. Agron. 27:25-87

Miller, R.D., J.H. Baker, and J.H. Kolaian. 1960. Particle size, overburden pressure, pore water pressure and freezing temperatures of ice lenses in soil. Trans. 7th Int. Congr. Soil Sci. 1:122-129.

Ross, D.J. 1970. Effects of storage on dehydrogenase activities of soils. Soil Biol. Biochem. 2:55-61.

Ross, D.J. 1971. Some factors influencing the estimation of dehydrogenase activities of some soils under pasture. Soil Biol. Biochem. 3:97-110.

Salfeld, J.C., and H. Sochtig. 1977. Jahreszeitliche Anderung der Humuszusammensetzung in einem Ackerboden. Mitt. Dtsch. Bodenkundl. Ges. $25: 265-270$

Skujins, J. 1973. Dehydrogenase: An indicator of biological activities in arid soils. Bull. Ecol. Res. Comm. (Stockholm) 17:235-241.

Skujins, J. 1976. Extracellular enzymes in soil. CRC Crit. Rev. Microbiol. 4:383-421

Smoliak, S. 1974. Range vegetation and sheep production at three stocking rates on Stipa-Bouteloua prairie. J. Range Manage. 27:23-26.

Smoliak, S., J.F. Dormaar, and A. Johnston. 1972. Long-term grazing effects on Stipa-Bouteloua prairie soils. J. Range Manage. 25:23-26.

Stott, D.E., and C. Hagedorn. 1980. Interrelation between selected soil characteristics and arylsufatose and urease activities. Commun. Soil Sci. Plant Anal. 11:935-955.

Tabatabai, M.A., and J.M. Bremner. 1969. Use of $p$-nitrophenyl phosphate for assay of soil phosphatase activity. Soil Biol. Biochem. 1:301-307.

Tabatabai, M.A., and J.M. Bremner. 1972. Assay of urease activity in soils. Soil Biol. Biochem. 4:479-487.

Thompson, S.o. 1965. Comparative properties of plant lignins and soil humic substances. Ph.D. thesis, University of Wisconsin, Madison. 